\title{
Reducing Barriers to Services Trade: The U.S. Case
}

\author{
Lawrence J. White \\ Stern School of Business \\ New York University \\ Lwhite@stern.nyu.edu \\ Presented at the Conference on \\ "Sleeping Giant: The Transatlantic Services Market" \\ at the Center for Transatlantic Relations \\ Paul H. Nitze School of Advanced International Studies \\ Johns Hopkins University \\ February 8, 2007
}

Revised draft: March 13, 2007

Please do not cite or quote without the permission of the author

Comments welcomed

\begin{abstract}
$\underline{\text { Abstract }}$
Though the U.S. economy is generally open with respect to international trade in services, there are some notable exceptions as well as some more subtle problems. This essay provides a brief primer on trade in services, examines recent world and U.S. data, and highlights the major trade barriers, the opportunities, and the policy dangers that lurk in the current political climate.
\end{abstract}

Keywords: trade in services; barriers; regulation; GATS

JEL codes: F13; F14 


\title{
Reducing Barriers to Services Trade: The U.S. Case
}

\author{
Lawrence J. White* \\ Stern School of Business \\ New York University \\ Lwhite@stern.nyu.edu
}

\section{$\underline{\text { I. Introduction }}$}

Reducing the barriers to international trade in services provides all of the usual opportunities and challenges for the United States economy: The potential reductions in the U.S. barriers provide the opportunities for improvements in the allocations of U.S. resources, with commensurate improvements in productivity and welfare. Further, because the U.S. has a comparative advantage in a number of major services areas -- such as airline services, financial services, educational services, many professional services, entertainment services, etc. -- the U.S. economy could also gain from reductions in services trade barriers abroad. But, because of the mercantilist orientation of most trade negotiations, the reductions in barriers abroad would likely require that the U.S reduce its barriers. But the losing parties from the reductions in the U.S. barriers have opposed and will surely continue to oppose such reductions.

All of this is standard stuff for trade barrier reductions. There are additional features, however, that make reductions in trade barriers for services -- and the avoidance of the erection of new barriers -- especially interesting and worthwhile for the U.S.: International trade in services is an area that is growing faster than trade in goods -- for the world generally and for the U.S. specifically. Also, unlike trade in goods, where for over a decade the U.S. has run ever-increasing annual net deficits, the U.S. continues to run

\footnotetext{
* This essay draws heavily in some places on White (2001, 2002b, 2005). I would like to thank Christine McDaniel for useful comments on an earlier draft.
} 
surpluses in trade in services. Also, trade in services is a growth area in terms of the amount of attention -- analytic as well as diplomatic -- that is being paid to it.

This essay will focus on trade in services and specifically on the recent U.S. experience and some U.S. issues. ${ }^{1}$ Section II offers a brief primer on trade in services itself. Section III next examines recent trade-in-services statistics for the world and for the U.S. Section IV then turns to a description of the current orientation of the U.S. toward services trade, the major existing restrictions and the ripe opportunities for reductions in U.S. trade barriers, and the dangers of new restraints. Section V provides a brief conclusion.

${ }^{1}$ Since this essay focuses on the U.S., "foreign" corporations will mean those companies that are headquartered outside of the U.S., while "domestic" or "U.S." corporations will mean those companies that are headquartered in the U.S. 


\section{$\underline{\text { II. Trade in Services -- A Primer }}$}

Services are usually not the first thing that most people visualize when they think of international trade. Instead, it is trade in goods -- represented by sacks of grain, rolls of steel, barrels of oil, boxes of toys and electronic goods, etc. -- that is most readily visualized and that is often the subject of newspaper stories about trade and of policy debates about trade.

This is probably to be expected. Goods are concrete; their movement can be physically tracked as they cross borders from one country to another. Their concreteness helps in documentation and data gathering, as well as in understanding trade impediments such as tariffs and quotas.

By contrast, services are intangible; they can't be seen, touched, held, or felt. It is no accident that international flows of services used to be described as "invisibles". They flow internationally in different ways than do goods, so that the standard trade impediments (tariffs and quotas) usually don't apply. Also, services are more likely to be subject to direct domestic regulation of their delivery, which then opens opportunities for more subtle (or, perhaps, not so subtle) trade restrictive efforts through this regulation. In recognition of these differences, the inception of the World Trade Organization (WTO), as the successor to the General Agreement on Tariffs and Trade (GATT) in 1995, brought with it a separate document and negotiating forum (under the umbrella of the WTO): the General Agreement on Trade in Services (GATS).

These differences, and the likely lesser general familiarity with trade in services, make a brief discussion of the basics of trade in services worthwhile.

\section{A. The four modes of trade in services.}

As was noted above, services often don't flow across borders in the same way as goods flow. In recognition of this difference, a four-part classification system for services 
flows has developed and is generally accepted: ${ }^{2}$ (1) cross-border; (2) consumption abroad; (3) commercial presence; and (4) temporary presence (presence of natural persons). We expand on each category below.

1. Cross-border. Some services can and do actually originate in one country and "move" across a border to a user-recipient in another country. Examples include:

- electricity;

- telephone and similar telecommunications services;

- the transportation and logistics services that attach to the physical movement of goods in international trade;

- the transportation of people across borders;

- the sales services that attach to a sale (of goods or services) across borders;

- the provision of a loan, deposit, insurance, or other financial services product across a border;

- distance learning, whereby a student in one country takes a course (e.g., via the Internet) offered by an educational institution in another country.

2. Consumption abroad. Some services are consumed through the travel of the customer from one country to the provider in another country. Examples include:

- tourism;

- education abroad;

- repair services abroad;

- medical treatment abroad.

3. Commercial presence. For many services, the service is most effectively provided/sold to the customer through a local physical establishment in the country of the

\footnotetext{
2 These four modes are specified in article I of the GATS. Standard discussions of trade in services provide the examples listed below in the text, as well as other examples, and expand on them. See, for example, Bressand and Nicolaidis (1989), Hoekman and Braga (1997), Aharoni and Nachum (2000), Sauve and Stern (2000), Stephenson (2000), Findlay and Warren (2000), Hoekman (2000), Stern (2001), and Mattoo and Sauve (2003).
} 
consumer. For example, though a loan could (in principle) be made by a bank that was located solely in country $\mathrm{X}$ to a borrower who was located solely in country $\mathrm{Y}$ (and thus be a "cross-border" transaction along the lines of \#1 above), the bank's ability to assure itself that the borrower was a good risk who would be likely to repay the loan would usually be enhanced by the bank's having a local branch ("commercial presence") in country Y for interviewing and monitoring the borrower. As another example, a restaurant chain or a hotel chain in country X may believe that its services would be attractive also to customers in country $\mathrm{Y}$, but few of the latter would be willing to travel to country $\mathrm{X}$ just for those services. In this case, the establishment of local outlets in country Y may be the only way for those services to be delivered.

More generally, examples of services providers through "commercial presence" would include:

- banks and other financial services providers;

- restaurant chains;

- hotel chains;

- retail merchandise chains;

- accountancy branches;

- legal services branches.

Since "commercial presence" does require a physical presence, the provision of services through this channel will usually require investment in the host country from the services firm in its home country (i.e., foreign direct investment, or FDI). Also, home country personnel may need to travel to the location abroad (i.e., the host country) so as to initiate the operations, train local personnel, periodically monitor the operations, etc. Thus, this mode brings other international transactions -- FDI and labor movement -- with it. In turn, these additional international flows mean that there are more (and more subtle) opportunities for host countries to impede the flow of services from abroad through 
restrictions on FDI and restrictions on immigration, as well as through more direct limitations on commercial location and establishment itself.

4. Temporary presence (presence of natural persons). Some services may be best delivered through the temporary presence of an individual or a group of individuals who deliver the service while abroad. Examples include:

- visiting entertainers (e.g., visiting orchestras, theater companies, rock stars);

- temporary consultancies;

- short-term construction projects.

Again, because individuals from a home country must travel to a host country in order to deliver the service, immigration policy can become an indirect means of impeding the flow of the service.

\section{B. Domestic regulation.}

Services are often subject to extensive regulation by governments. As one illustration, consider the set of industries that were considered to be extensively regulated in the U.S. in the 1960s and 1970s and that were the targets of major efforts at deregulation or regulatory reform during the last quarter of the twentieth century: ${ }^{3}$

- air transport;

- rail transport;

- truck transport;

- water transport;

- natural gas pipeline transport;

- petroleum pipeline transport;

- telephone;

- broadcasting;

\footnotetext{
${ }^{3}$ See, for example, Joskow and Rose (1989), Noll (1989), Winston (1993), and Joskow and Noll (1994).
} 
- electricity;

- banking;

- securities;

- insurance.

All of these industries are services providers. Further, though this list is drawn from the U.S. experience, in other countries these same industries were either also heavily regulated or were under government ownership.

Though these industries are considerably less regulated today in the U.S. than they were three decades ago, a remnant of regulation -- modest in some industries, still substantial in others -- persists today. Similarly, in many other countries, the partial deregulation or privatization over the past few decades has meant that greater or lesser remnants of regulation persist.

For another broad category of services -- e.g., professional services, such as medical services, legal services, accountancy services, architectural services, etc. -- government regulation occurs through licensing boards (or through delegation to professional associations, with government oversight) that are intended to maintain quality standards, prevent fraud, and protect the public.

Government regulation of the various kinds of services industries adds a layer of complexity to efforts to reduce impediments to international trade in services, since the regulatory regimes themselves can become separate centers of resistance to the removal of barriers.

\section{A paucity of data}

Another special feature of services is the relative paucity of detailed data with respect to services, as compared with manufacturing in the U.S. and elsewhere. Despite the fact that services in the U.S. now account for over $75 \%$ of private-sector GDP and $75 \%$ of private-sector employment, while manufacturing accounts for only $15 \%$ and $12 \%$, respectively, the quantity of data and the levels of detail that are available for the 
manufacturing sector - say, from the semi-decennial economic censuses or from international trade data - far exceed those that are available for the services sector. This disparity is a legacy from the 1930s, when the basic statistical-gathering functions of the federal government were established and manufacturing was substantially more important in the U.S. economy. Though efforts are being made to rectify this disparity, ${ }^{4}$ it still hobbles efforts to understand services - and trade in services - at a deeper level.

\section{The GATS.}

Through the mid 1970s there was little perception that trade in services was an important enough phenomenon to warrant substantial attention. ${ }^{5}$ Instead, virtually all of the post-World War II multilateral effort at trade liberalization was focused on trade in goods through the General Agreement on Tariffs and Trade (GATT).

In the late 1970s, however, as the U.S. began the deregulation of its domestic airline industry, the same commitment to greater competition (and the dawning realization that the U.S. had a comparative advantage) began manifesting itself internationally through U.S. efforts to negotiate bilateral "open skies" arrangements to reduce the impediments that U.S. airlines faced abroad. Further, the U.S. was also increasingly concerned about how other countries were treating the overseas branches of U.S. banks and how U.S. entertainment services, such as movies and syndicated television programs, were being treated. In addition, the European Common Market (ECM) was recognizing that the flows of various kinds of services, among its member countries and between the ECM and the rest of the world, was a major task that warranted substantial attention. In the early 1980s the U.S. began a concerted effort to bring trade in services into the realm of multinational negotiation and bargaining.

\footnotetext{
${ }^{4}$ See, for example, Lazear (2007).

${ }^{5}$ A more extensive treatment of the diplomatic history that eventually led to the GATS can be found in Nicolaidis (1989).
} 
During the Uruguay Round of GATT negotiations in the late 1980s and the early 1990s there was a more general international realization that trade in services needed to be brought into a more formal multilateral negotiating arena. As a consequence, along with the formation of the World Trade Organization (WTO) itself as the successor to the organization that had administered the GATT, a general agreement on trade in services -the GATS -- was negotiated, and the GATT and the GATS became parallel pillars of the newly formed WTO. ${ }^{6}$ The GATS (with a Council on Trade in Services to administer it) came into effect on January 1, 1995.

The GATS is a broad set of principles that has the goal of encouraging freer trade in services among the WTO member countries. It applies to virtually all services, with the exception of government services that are non-commercial in nature (e.g., social insurance, public safety, national defense) and air traffic rights. It establishes general commitments toward most-favored nation (MFN) treatment, transparency in the domestic regulation of services, market access, and national treatment of services suppliers. It formally recognizes that services can be delivered through any of the four modes discussed above.

Unfortunately, the GATS is also riddled with loopholes and exceptions, which are the formal recognition in the GATS of the sensitivities and difficulties that come with many services sectors, especially those that are regulated along the lines discussed above. The most important loophole is that each country can choose which of its services sectors, through which mode, will be subject to the specific provisions of the GATS (and, implicitly, which will be exempt). Further, the leadership of the GATS and of the WTO, in deference to national sensitivities about domestic regulatory issues, have stressed the ability of governments to limit their commitments to removing barriers. ${ }^{7}$

\footnotetext{
${ }^{6}$ An "Agreement on Trade-Related Aspects of Intellectual Property Rights" (TRIPS) was also negotiated during the Uruguay Round and also placed within the WTO.

${ }^{7}$ See, for example, WTO (2001).
} 
Actual progress in effecting reductions in services trade barriers -- because of all of the sensitivities to regulatory issues -- has been slow. ${ }^{8}$ The GATS has been in existence for about twelve years. After an initial set of statements and commitments at its inception, the "serious" negotiations were supposed to occur after 2000 in what has come to be called the Doha Round, with the negotiated reductions to be put in place at the end of the Round. Unfortunately, the Doha Round fell apart in July 2006 over a range of issues, and it is unclear what will happen next and also unclear whether any negotiated reductions will actually occur.

Further, the structure of the GATS and its substantial deference to domestic regulation has created a seemingly inherent bias toward inaction. ${ }^{9}$ The efforts aimed at reducing barriers to trade in accountancy services are a good example. ${ }^{10}$ Early in its existence the Council on Trade in Services chose accountancy as a lead sector (among the heavily regulated professional services sectors) for more detailed and extensive negotiations aimed at reducing trade barriers, because accountancy already had substantial international presences through the international expansions of a (literal) handful of large accountancy firms. In 1998 the Council adopted "disciplines" (rules) on the domestic regulation of accountancy that were intended to provide greater detail on issues of transparency, licensing requirements and procedures, qualification requirements and procedures, and technical standards. The disciplines were not to come into force, however, until the conclusion of the Doha Round (which has fallen apart). When the GATS announced a "Workshop on

${ }^{8}$ This is the clear tenor of the essays in Mattoo and Sauve (2003), with the possible exception of the essay (Roseman, 2003) on telecommunications.

9 The arcane and opaque terminology of the GATS -- "schedules", "bindings", "disciplines", "negative lists", etc. -- surely does not enhance outsiders' understanding and monitoring of the process.

${ }^{10}$ More details can be found in White (2001, 2005) and Trolliet and Hegerty (2003). 
Domestic Regulation" that was to be held on March 29-30, 2004, and highlighted accountancy, the most recent progress that it could cite in that area was the 1998 disciplines.

Excerpts from the "Abstract" and "Introduction" sections of two recent GATS Working Papers ${ }^{11}$ provide excellent expressions of the exceedingly modest progress that has been achieved under the GATS:

"...Members have more scope than under the GATT to depart from common horizontal obligations, in particular the MFN principle; they are able to adjust the breadth and depth of their trade commitments (market access and national treatment) to particular sector conditions; and they face less constraints, if any, in the use of trade-related policies such as subsidies, export restrictions, or domestic regulatory interventions... [T] he basic (builtin) flexibility elements of the Agreement ... will, of course, persist... However, flexibility may come at a cost: lack of meaningful obligations across a reasonably broad range of service sectors. Vested interests may find it far easier than under the GATT to defend their privileges and defy more rational and harmonized trading conditions... (Adlung, 2004, p. 1)

"The ... absence of major problems [within the GATS] to date may be attributed to at least three factors:... Second, the lack of stringent, nonmodifiable trade obligations. There are virtually no requirements that individual Members might find difficult to meet or, otherwise, elude under relevant exemptions. The GATS offers more scope for departures from most-favored-nations (MFN) treatment -- one of the few horizontal obligations that apply across virtually all services -- than is the case under relevant GATT Articles. Moreover, traditional building blocks of the GATT, including the prohibition of quantitative restrictions and the automatic guarantee of national treatment with regard to domestic rules and regulations, are negotiable under the GATS..." (Adlung, 2004, p. 2)

"Over the past months, it has become increasingly clear that the services negotiations under the Doha Development Agenda will not produce significant improvements on current commitments unless major new impetus is provided... [T]his paper discusses various impediments, from the perspective of the participating governments, that may explain the lack of negotiating momentum to date..." (Adlung and Roy, 2005, p. 2)

"The services commitments that resulted from the Uruguay Round (1986-1993/94), the first such round to cover trade in services as well, apparently have not had significant liberalization effects. Barring a few exceptions in basic telecommunications and financial services, where negotiations continued until February and December 1997, respectively, the commitments inscribed in Members' schedules remained essentially

${ }^{11}$ See Adlung (2004) and Adlung and Roy (2005). 
confined to binding existing regimes in a limited number of sectors. Further, many commitments may have been overtaken by autonomous liberalization moves in individual countries... This paper seeks to explore why commitments under the GATS have generally remained modest..." (Adlung and Roy, 2005, p. 3) 


\section{$\underline{\text { III. Some Data }}$}

A priori, one would expect to see rising levels of international trade in services, for at least five reasons. First, services generally appear to have an income elasticity of demand that is substantially greater than 1.0, especially in developed economies. As developed countries grow, they tend to produce and consume more-than-proportionately greater levels of services. To the extent that any services can cross borders, we would expect the growing demand for services to affect these cross-border services as well, which would be captured in economic statistics as growth in international trade in services. ${ }^{12}$

Second, the technologies -- telecommunications, data processing and digitization, transportation, biological sciences -- that underlie many important categories of services have experienced rapid improvements in the past few decades. ${ }^{13}$ As a consequence, better quality services, with greater variations and variety, can be offered by more firms at lower costs over longer distances; more effective competition among providers follows. The real prices (quality-adjusted and inflation-adjusted) of many services has surely decreased, which reinforces the income-elasticity effects to encourage greater consumption of services. And, again, some of this greater consumption should spill over to international trade in services.

Third, the improvements in telecommunications, data processing, and transportation technologies have also allowed firms to operate effectively over longer geographic distances and thus to allow services providers (such as hotel and restaurant chains) that require a commercial presence to be able to expand their reach and offerings.

Fourth, digitization of various kinds of information -- e.g., credit scores of potential borrowers, the X-rays of medical patients, etc. -- and reduced telecommunications costs

\footnotetext{
${ }^{12}$ For recent estimates of the income and price elasticities of demand that pertain to major categories of U.S. exports and imports of services, see Marquez (2005).

${ }^{13}$ See Bosworth and Triplett (2004) for a general discussion.
} 
have permitted some services (credit assessment, X-ray reading) that were previously vertically integrated with the final service (making a loan, health care) to be "outsourced". With low-cost telecommunications extending internationally, the outsourced services can become "offshored" internationally traded services. ${ }^{14}$

Finally, to the extent that countries have reduced their barriers to trade in services, those reductions too should encourage greater growth.

As we will see, the data strongly support these predictions. We will first present briefly some world trade data and then some more extensive U.S. data.

\section{A. World data.}

Table 1 shows the experience of the world trading system for the past quarter century for goods and services. Consistent with the brief discussion above, trade in services has grown substantially: faster than trade in goods, and faster than the growth in world GDP. It is worth noting that these data exclude the "commercial presence" mode (mode \#3 above) of services exports, which has probably grown even faster (at least as is indicated by the U.S. data that are discussed below).

Table 2 shows the identity of the leading exporters and importers of goods and services, as of 2005. As would be expected, the world's largest economies are the world's leading traders as well, with the U.S. holding first place in three of the four categories and second in the fourth.

B. U.S. data.

Table 3 shows the experience specifically of the U.S. over this same quarter century. Again, consistent with the discussion above, trade in services has grown substantially: faster than trade in goods and faster than U.S. GDP, as well as faster than world trade in services.

\footnotetext{
${ }^{14}$ For further discussions along these lines, see Mann (2005), Jensen and Kletzer (2006), Van Welsum and Reif (2006), and (more generally) Collins and Brainard (2006).
} 
Table 4 provides the year-by-year annual trade data for goods and services for 19922005. As can be readily seen, trade in services has maintained a consistent annual surplus, while the annual deficit in trade in goods has grown progressively larger.

Table 5 provides annual data for 1992-2005 for finer categories of services trade. ${ }^{15}$ Travel (i.e., tourism) has shown modest growth rates on both the export and import sides. Passenger fares (largely airline fares plus cruise lines) showed slow growth in exports but much larger growth in imports. Other transportation (i.e., ocean shipping, air freight, ocean port services, and airport services) showed faster growth of imports than of exports. Royalties and license fees (mostly fees paid to affiliates for intellectual property, plus fees paid for broadcasting international sports events) grew substantially, especially on the import side. Other private services (including education; financial services; insurance; telecommunications; film and television tape rentals; and business, professional, and technical services) grew rapidly; ${ }^{16}$ finally, U.S. military and other government services grew at slow to medium rates.

Finally, Table 6 shows the annual data for 1992-2005 for sales of services through nonbank affiliates -- in essence, sales of services through a commercial presence (mode \#3 discussed above). As can be seen, the flows in both directions grew faster than did the services flows shown in Table 4. Further, sales by foreign affiliates of U.S. companies to non-U.S. persons grew faster than the sales by the U.S. affiliates of foreign companies to U.S. persons, and the net balance was a growing and sizable surplus. It is also worth noting that for recent years the absolute sizes of the services sales in each direction have been larger than the counterpart services exports and imports listed in Table 4, and the annual surpluses

\footnotetext{
${ }^{15}$ Greater detail and discussion can be found in Koncz et al. (2006) and USITC (2006).

16 The persistent annual surpluses in this category are prominently noted in USCEA (2005, pp. 178-179).
} 
for 2003 and 2004 in Table 6 are also larger than the services surpluses in Table 4 for the same years. 


\section{$\underline{\text { IV. Opportunities for Reductions in Trade Barriers }}$}

\section{A. The general landscape.}

The U.S. economy -- with some notable exceptions -- is generally open to non-U.S. providers of services through any of the four modes. ${ }^{17}$ Even in relatively open areas, however, there are some subtle problems.

Financial services provide a good example. As a general matter, with respect to financial services the U.S. generally does not discriminate against non-U.S. banks or securities firms or insurance companies, and non-U.S. firms have developed sizable shares of the U.S. market (as measured by assets or other standard metrics). ${ }^{18}$ As a first subtle problem, however, since financial services are frequently regulated by the 50 states as well as by the U.S. Government, ${ }^{19}$ anomalous state regulations sometimes make entry and establishment by foreign firms somewhat harder than is true for U.S. firms. ${ }^{20}$

Second, in the area of housing finance, the U.S. has chartered three large "government-sponsored enterprises" (GSEs) -- Fannie Mae, Freddie Mac, and the Federal Home Loan Bank System -- that are private companies with special privileges and advantages. $^{21}$ The most important advantage is the reduced borrowing costs that these GSEs enjoy as a consequence of their GSE status and the financial markets' perception that the U.S. Government would likely "bail them out" and thus make their creditors whole in

17 See the discussions in Brewer and Young (2001), Mann (2005), WTO (2006b) and USITC (2006).

${ }^{18}$ See, for example, the data and discussion in White (2002a).

${ }^{19}$ Insurance is an exception, in that it is regulated solely by the states.

${ }^{20}$ Further discussion on this point can be found in USITC (2002, ch. 5) and WTO (2006b).

${ }^{21}$ Further discussion of these GSEs can be found, for example, in Frame and Wall (2002), Frame (2003), White (2003, 2004), Frame and White (2004, 2005), and Frame and Flannery (2006). 
the event of financial difficulties at any of the GSEs. Only these three GSEs have these special charters, and the Congress is unlikely to create more such charters. Consequently, this special area of housing finance ${ }^{22}$ is effectively barred to new entry and competition from new firms with such charters -- whether the firms are foreign or domestic.

Third, the major bond rating companies (e.g., Moody's, Standard \& Poor's, and Fitch) have been protected since 1975 by a little-known set of Securities and Exchange Commission (SEC) regulations. ${ }^{23}$ These regulations created a category "Nationally Recognized Statistical Rating Organization" (NRSRO) and "grandfathered" the three major firms into the category. Though the SEC subsequently designated four more firms as NRSROs, by 2000 mergers among the four and with Fitch had reduced the number of NRSROs back to the original three.

The importance of the NRSRO designation lies in the following: Many categories of regulated financial services firm are restricted as to the quality of bonds that they can hold in their portfolios (i.e., in which they can invest). For example, commercial banks and other depository institutions are permitted to hold only "investment grade" bonds. Crucially, only the NRSROs' designations of quality (e.g., their designations of "investment grade") matter for the financial institutions' choices -- and thus the absence of the NRSRO designation causes a would-be bond rating firm to be at a substantial disadvantage.

Moody's and S\&P are U.S. companies; Fitch is the subsidiary of a French conglomerate. There is no evidence that the SEC has any "home company" bias. Indeed, when (under Congressional pressure) in early 2003 the SEC designated a fourth NRSRO, it chose a Canadian bond rating company, Dominion Bond Rating Services (DBRS). ${ }^{24}$

\footnotetext{
${ }^{22}$ It is important to note, however, that entry into housing finance more generally is open to foreign firms as well as to domestic firms.

${ }^{23}$ For expansion on this topic, see White (2002b, 2006, 2007).

24 When the SEC designated a fifth NRSRO in early 2005, it chose A.M Best, an insurance company specialist.
} 
Nevertheless, it is clear that the SEC's NRSRO designation is a barrier to entry into the bond rating business in the U.S. and thus a restriction on trade in services if a foreign firm would otherwise want to enter and provide bond rating services in the U.S. (as DBRS had desired prior to 2003, and as other foreign firms have indicated to the SEC). ${ }^{25}$

There are likely other such subtle restrictions on trade in services that are strewn across the regulatory landscape in the U.S.

B. The major restrictions.

There are four major areas for which there are notable restrictions on trade in services in the U.S.: air transport; water transport; truck transport; and satellite broadcasting spectrum licenses. We will discuss each in turn. ${ }^{26}$

1. Air transport. Under the Civil Aeronautics Act of 1938 and the Federal Aviation Act of 1958, any company that provides point-to-point passenger or freight air service within the U.S. ("cabotage") must be a U.S. carrier. This means that the company must be under the actual control of U.S. citizens, and foreign ownership is limited to a maximum of $25 \%$ of voting shares. Also, the president and at least two-thirds of the board of directors and other managing officers must be U.S. citizens. The crews of a U.S. carrier must be U.S. citizens or resident aliens.

All of these requirements have effectively prevented foreign carriers from offering domestic service in the U.S.

In addition, the Fly America Act of 1974 requires that U.S. government-financed international transportation of passengers and cargo be on a U.S.-flag carrier (although exceptions are possible).

\footnotetext{
${ }^{25}$ In the late summer of 2006 new legislation was passed that was intended to loosen the SEC's restrictions on entry into the bond rating business. Whether that intent will be converted into actuality will be determined by how the SEC drafts and implements the new regulations that are required by the legislation. For further discussion, see White (2007).

${ }^{26}$ Extensive discussions of these restrictions and their consequences can be found in USITC (1999, ch. 5; 2002, ch. 5; 2004, ch. 5)
} 
2. Water transport. The Jones Act of 1920 restricts the domestic point-to-point transport of cargo to ships that are registered and built in the U.S., on which at least $75 \%$ of the employees are U.S. citizens, and that are owned by a U.S. corporation. Domestic passenger service (essentially, cruise lines) must meet similar requirements under the Passenger Vessel Services Act of 1886. Though foreign companies could, in principle, establish a shipping company in the U.S. through a holding company arrangement, the other requirements have effectively discouraged such actions, and U.S. water-borne cabotage is a U.S. preserve.

In addition, various pieces of legislation require that 50\%-100\% (depending on the category) of "government-impelled" international cargoes -- such as military cargo, oil for the Strategic Petroleum Reserve, and foreign aid cargo -- be carried in U.S.-flag ships (that are built in the U.S., on which at least $75 \%$ of the employees are U.S. citizens, and that are owned by a U.S. corporation). Despite these restrictions, $98 \%$ of U.S. international waterborne cargo travels in non-U.S. flag ships. Nevertheless, the restrictions on the remaining $2 \%$ are effectively a restraint on trade.

3. Truck transport. Realistically, the import of trucking services is likely to occur largely from Canada and Mexico. Neither country's trucks are permitted to provide domestic point-to-point freight service within the U.S.; ${ }^{27}$ thus, yet another category of cabotage is reserved for U.S. firms.

The use of foreign-owned trucks for the delivery of international cargo to points within the U.S. is a separate, and important, category of concern. About $70 \%$ of goods imports from Canada enter the U.S. by truck; the comparable figure for goods imports by truck from Mexico is over $80 \%$.

${ }^{27}$ A modest exception is available to Canadian trucks that are delivering or picking up international cargoes in the U.S.; they can transport goods between points within the U.S., so long as the local shipment is incidental to an immediately prior or subsequent international trip. 
Efforts began in the 1980s to harmonize regulations between the U.S. and Canada. These efforts continued under the U.S.-Canada Free Trade Agreement of 1988 and the North American Free Trade Agreement (NAFTA) of 1992, so that delivery of international cargoes by Canadian trucks is currently not considered to be a major problem.

With respect to the use of Mexican-owned trucks for the delivery of international cargoes, however, the picture is quite different. Despite specific provisions in NAFTA for the progressive expansion of the reach of Mexican trucks to all points in the U.S., Mexican trucks are still (as of 2007) restricted to deliveries within a few miles of the border, necessitating costly and inefficient cargo transfers for most cargoes from Mexico.

4. Satellite broadcasting spectrum. The Communications Act of 1934 restricts the granting of electromagnetic spectrum licenses to U.S. citizens or corporations; but it is possible for a foreign company to establish a holding company that owns a U.S. corporation that has such licenses.

However, the Communications Act also restricts foreign ownership of one-way satellite transmissions of direct-to-home (DTH), direct broadcasting systems (DBS), and digital audio services, and the holding company work-around does not appear to be available to undo this restriction.

\section{The opportunities and the challenges.}

As is true in other areas of international trade, the U.S. Government's position with respect to trade in services is a mixture of export boosterism and import protectionism. On the one hand, in areas in which the U.S. has a comparative advantage -- such as international airline services, financial services, and entertainment services -- the U.S. has been actively promoting "open skies" and its financial and entertainment equivalents. On the other hand, in areas where the U.S. has a comparative disadvantage, such as ocean shipping, or where important national interests are seen to be at stake, such as domestic airline service or satellite services, the U.S. remains protectionist. 
This bifurcation in perspective is largely typical of the mercantilist perspective that continues to dominate national policy-making: Exports are good; imports are bad; "jobs" saved and created are all-important; we will (maybe) lower our trade barriers only if you promise to lower yours; etc. It pervades the U.S. policy perspective with respect to trade in goods. There's no reason to expect that it wouldn't pervade trade in services as well.

It is clear that there would be net gains in U.S. social welfare if the major restrictions identified above were relaxed, even unilaterally. ${ }^{28}$ Further, because the U.S. has a comparative advantage in many important services -- e.g., airline services, educational services, financial services, entertainment services, etc. -- the U.S. economy could also gain from reductions in services trade barriers abroad. These latter reductions could well require, as a quid pro quo, the reductions in the major U.S. barriers. However, the reduction or removal of these major restrictions -- which would require contentious legislation ${ }^{29}$-- do not seem to be "on the table" for discussion and negotiation. ${ }^{30}$

There are two other trade-in-services issues that are of concern. First, as a consequence of the events of September 11, 2001, the U.S. clearly tightened its immigration procedures, which must make it harder for foreign services providers to maintain their efforts in the U.S. Substantial levels of illegal immigration into the U.S. have generated

${ }^{28}$ The "national defense" argument for retaining these restrictions on domestic air service and waterborne trade are weak, at best, and the goals could be achieved at lesser social costs through various contingent contracting arrangements by the U.S. Department of Defense. The "highway safety" arguments that are used to justify the restrictions on Mexican trucking in the U.S. are similarly weak.

${ }^{29}$ Beginning in late 2005 the U.S. Department of Transportation explored the possibility that it could (through a liberal interpretation of the relevant legislation) find a way around the foreign ownership restrictions on domestic airline service (so as to accommodate the possibility of the Virgin Group's establishing domestic service) but ultimately abandoned the effort in December 2006.

${ }^{30}$ In its initial policy statement that was preliminary to the WTO's 2006 "Trade Policy Review", the U.S. did not mention any of its major services trade restrictions. See WTO (2006a). 
calls for a general reform of immigration policy. There are always dangers that changes in immigration policy could further restrict the inflow of foreign workers, with unfortunate consequences for trade in services.

Second, there has been a rising level of political attention to the offshore outsourcing of some services, such as telephone call centers, backoffice data processing, software development, and other information technology functions. This outsourcing has grown as a consequence of decreasing telecommunications and data processing costs and the generally

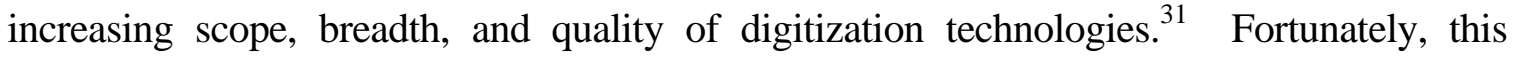
greater political attention has not (yet) been translated into any restrictive actions or policies. But the possibility of restrictions surely continues as a worrisome threat to freer trade in these services.

${ }^{31}$ See Mann (2005) and Van Welsum and Reif (2006). 


\section{$\underline{\text { V. Conclusion }}$}

Trade in services is a growing and worthwhile area for the U.S. and the world. Though the U.S. is a comparatively open economy with respect to trade in services (as well as trade in goods), there are some major restrictions that are worthy of relaxation, as well as some more subtle problems. Further, since the U.S. has a comparative advantage in a number of major services areas, the U.S. economy would benefit from the relaxation of restrictions abroad. Finally, policy concerns about immigration (which is essential for many forms of trade in services) and about the offshore outsourcing of some services could lead to new restrictions, with unfortunate consequences for trade in services.

Though the long-run trends of reduced restrictions on and expanded flows of trade in services have been favorable and probably will continue to be so, the attractiveness of protectionism and mercantilism should never be underestimated. Wary optimism and watchful readiness may well be the best attitudes for those who care about maintaining and open environment for trade in services. 


\section{$\underline{\text { References }}$}

Adlung, Rudolf, "The GATS Turns Ten: A Preliminary Stocktaking," Staff Working Paper ERSD-2004-05, WTO, August 2004.

Adlung, Rudolf and Martin Roy, "Turning Hills into Mountains? Current Commitments under the GATS and Prospects for Change," Staff Working Paper ERSD-2005-01, WTO, March 2005.

Aharoni, Yair and Lilach Nachum, Globalization of Services: Some Implications for Theory and Practice. London: Routledge, 2000.

Bressand, Albert and Kalypso Nicolaidis, eds., Strategic Trends in Services: An Inquiry into the Global Service Economy. New York: Ballinger, 1989.

Brewer, Thomas L. and Stephen Young, "The USA in the WTO," in Alan M. Rugman and Gavin Boyd, eds., The World Trade Organization in the New Global Economy: Trade and Investment Issues in the Millennium Round. Northampton, Mass.: Edward Elgar, 2001.

Collins, Susan M. and Lael Brainard, eds., Brookings Trade Forum 2005: Offshoring WhiteCollar Work -- the Issues and the Implications. Washington, D.C.: Brookings, 2006.

Findlay, Christopher and Tony Warren, eds., Impediments to Trade in Services: Measurement and Policy Implications. London: Routledge, 2000.

Frame, W. Scott, "Federal Home Loan Bank Purchases: Implications for Mortgage Markets," Economic Review, Federal Reserve Bank of Atlanta, 88 (Third Quarter 2003), pp. 17-31.

Frame, W. Scott and Mark J. Flannery, "The Federal Home Loan Bank System: The 'Other' Housing GSE," Economic Review, Federal Reserve Bank of Atlanta, 91 (Third Quarter 2006), pp. 33-54

Frame, W. Scott and Larry Wall, "Financing Housing through Government-Sponsored Enterprises," Economic Review, Federal Reserve Bank of Atlanta, 87 (First Quarter 2002), pp. 29-43.

Frame, W. Scott and Lawrence J. White, "Regulating Housing GSEs: Thoughts on Institutional Structure and Design," Economic Review, Federal Reserve Bank of Atlanta, 89 (Second Quarter 2004), pp. 87-102.

Frame, W. Scott and Lawrence J. White, "Fussing and Fuming over Fannie and Freddie: How Much Smoke, How Much Fire?" Journal of Economic Perspectives, 19 (Spring 2005), pp. 159-184. 
Hoekman, Bernard M., "Towards a More Balanced and Comprehensive Services Agreement," in Jeffrey J. Schott, ed., The WTO after Seattle. Washington, D.C.: Institute for International Economics, July 2000, pp. 119-135.

Hoekman, Bernard M. and Carlos A. Primo Braga, "Protection and Trade in Services: A Survey," in Open Economies Review, 8 (July 1997), pp. 285-308.

Jensen, J. Bradford and Lori G. Kletzer, "Tradable Services: Understanding the Scope and Impact of Services Offshoring," in Susan M. Collins and Lael Brainard, eds., Brookings Trade Forum 2005: Offshoring White-Collar Work -- the Issues and the Implications. Washington, D.C.: Brookings, 2006, pp. 75-117.

Joskow, Paul L. and Roger G. Noll, "Economic Regulation: Deregulation and Regulatory Reform during the 1980s," in Martin Feldstein, ed., American Economic Policy in the 1980s. Chicago: University of Chicago Press, 1994, pp. 367-440.

Joskow, Paul L. and Nancy L. Rose, "The Effects of Economic Regulation," in Richard Schmalensee and Robert D. Willig, eds., Handbook of Industrial Organization, vol. 2. Amsterdam: North Holland, 1989, pp. 1449-1506.

Koncz, Jennifer, Michael Mann, and Erin Nephew, "U.S. International Services: CrossBorder Trade in 2005 and Sales through Affiliates in 2004," Survey of Current Business, 86 (October 2006), pp. 18-74.

Lazear, Edward P., "Remarks,” Chicago Council on Global Affairs: Chicago, IL, February 1, 2007; available at: http://www.whitehouse.gov/cea/lazear_cga020107.pdf

Mann, Catherine L., "Offshore Outsourcing and the Globalization of US Services: Why Now, How Important, and What Policy Implications," in C. Fred Bergsten, ed., The United States and the World Economy. Washington, D.C.: Institute for International Economics, 2005, pp. 281-311.

Marquez, Jaime, "Estimating Elasticities for U.S. Trade in Services," International Finance Discussion Paper No. 836, Board of Governors of the Federal Reserve System, August 2005.

Mattoo, Aaditya and Pierre Sauve, eds., Domestic Regulation and Service Trade Liberalization. Washington, DC: World Bank, and Oxford University Press, 2003.

Nicolaidis, Kalypso, "Learning while Doing: How Services Got on the Uruguay Round Agenda," in Albert Bressand and Kalypso Nicolaidis, eds., Strategic Trends in Services: An Inquiry into the Global Service Economy. New York: Ballinger, 1989, pp. 161-179.

Noll, Roger G., "Economic Perspectives on the Politics of Regulation," in Richard Schmalensee and Robert D. Willig, eds., Handbook of Industrial Organization, vol. 2. Amsterdam: North Holland, 1989, pp. 1253-1287. 
Roseman, Daniel, "Domestic Regulation and Trade in Telecommunications Services: Experience and Prospects under the GATS," in Aaditya Mattoo and Pierre Sauve, eds., Domestic Regulation and Service Trade Liberalization. Washington, DC: World Bank, and Oxford University Press, 2003, pp. 83-107.

Sauve, Pierre and Robert M. Stern, eds., GATS 2000: New Directions in Services Trade Liberalization. Washington, D.C.: Brookings Institution, 2000.

Stephenson, Sherry M., ed., Services in the Western Hemisphere: Liberalization, Integration, and Reform. Washington, D.C.: Brookings Institution, 2000.

Stern, Robert M., ed., Services in the International Economy. Ann Arbor: University of Michigan Press, 2001.

Triplett, Jack E. and Barry Bosworth, Productivity in the U.S. Services Sector. Washington, D.C.: Brookings, 2004.

Trolliet, Claude and John Hegerty, "Regulatory Reform and Trade Liberalization in Accountancy Services," in Aaditya Mattoo and Pierre Sauve, eds., Domestic Regulation and Service Trade Liberalization. Washington, D.C.: World Bank and Oxford University Press, 2003, pp. 147-166.

U.S. Council of Economic Advisers, Economic Report of the President. Washington, D.C.: USCEA, February 2005.

U.S. International Trade Commission, The Economic Effects of Significant U.S. Import Restraints, Second Update, Publication 3201. Washington, D.C.: USITC, May 1999.

U.S. International Trade Commission, The Economic Effects of Significant U.S. Import Restraints, Third Update, Publication 3519. Washington, D.C.: USITC, June 2002.

U.S. International Trade Commission, The Economic Effects of Significant U.S. Import Restraints, Fourth Update, Publication 3701. Washington, D.C.: USITC, June 2004.

U.S. International Trade Commission, Recent Trends in U.S. Services Trade: 2006 Annual Report. Washington, D.C.: USITC, June 2006.

Van Welsum, Desiree and Xavier Reif, "Potential Offshoring: Evidence from Selected OECD Countries," in Susan M. Collins and Lael Brainard, eds., Brookings Trade Forum 2005: Offshoring White-Collar Work -- the Issues and the Implications. Washington, D.C.: Brookings, 2006, pp. 165-194.

White, Lawrence J., Reducing the Barriers to International Trade in Accounting Services. Washington, D.C.: AEI Press, 2001. 
White, Lawrence J., "The Credit Rating Industry: An Industrial Organization Analysis," in Richard M. Levich, Giovanni Majnoni, and Carmen M. Reinhardt, eds., Ratings, Rating Agencies, and the Global Financial System. Boston: Kluwer, 2002a, pp. 41-64.

White, Lawrence J., "Unilateral Trade Openness: The Experience of the U.S. Financial Services Sector," in Jagdish Bhagwati, ed., Going Alone: The Case for Relaxed Reciprocity in Freeing Trade. Cambridge, Mass.: MIT Press, 2002b, pp. 445-481.

White, Lawrence J., "Focusing on Fannie and Freddie: The Dilemmas of Reforming Housing Finance. Journal of Financial Services Research, 23 (February 2003), pp. 43-58.

White, Lawrence J., "Fannie Mae, Freddie Mac, and Housing Finance: Why True Privatization is Good Public Policy," Policy Analysis, No. 528, Cato Institute, October 7, 2004.

White, Lawrence J., "International Trade in Services: More than Meets the Eye," in E. Kwan Choi and James C. Hartigan, eds., Handbook of International Trade: Economic and Legal Analyses of Trade Policy and Institutions, Vol. II. Malden, Mass.: Blackwell Publishing, 2005, pp. 472-498.

White, Lawrence J., "Good Intentions Gone Awry: A Policy Analysis of the SEC's Regulation of the Bond Rating Industry," Policy Brief \#2006-PB-05, Networks Financial Institute, Indiana State University, 2006.

White, Lawrence J., "A New Law for the Bond Rating Industry" Regulation, 30 (2007 forthcoming).

Winston, Clifford, "Economic Deregulation: Days of Reckoning for Microeconomists," Journal of Economic Literature, 31 (September 1993), pp. 1263-1289.

World Trade Organization, Council for Trade in Services, "Accountancy Services," December 4, 1998.

World Trade Organization, "GATS -- Fact and Fiction," 2001.

World Trade Organization, "Trade Policy Review: Report by the United States," March 3, 2006a.

World Trade Organization, "Trade Policy Review: Report by the Secretariat -- United States," June 20, $2006 \mathrm{~b}$. 
Table 1: World Trade and GDP Data, 2005

\begin{tabular}{|l|r|r|}
\hline & Levels, 2005 & Average annual \% change, 1980-2005 \\
\hline & & \\
\hline World trade: services & $\$ 2,415 \mathrm{~B}$ & $7.85 \%$ \\
\hline World trade: goods & $\$ 10,539 \mathrm{~B}$ & $6.74 \%$ \\
\hline World GDP & $\$ 44,455 \mathrm{~B}$ & $5.47 \%$ \\
\hline
\end{tabular}

Note: All values in nominal \$; average annual \% change is calculated as simple annual compounding of last year/first year

Sources: WTO; IMF 
Table 2: Leading World Exporters and Importers, 2005

\begin{tabular}{|l|l|l|l|}
\hline Goods Exports & Services Exports & Goods Imports & Services Imports \\
\hline & & & \\
\hline Germany & U.S. & U.S. & U.S. \\
\hline U.S. & U.K. & Germany & Germany \\
\hline China & Germany & China & U.K. \\
\hline Japan & France & France & Japan \\
\hline France & Japan & U.K. & France \\
\hline
\end{tabular}

Source: WTO 
Table 3: U.S. Trade and GDP Data, 2005

\begin{tabular}{|l|r|r|}
\hline & \multicolumn{1}{|l|}{ Levels, 2005 } & Average annual \% change, 1980-2005 \\
\hline & & $8.67 \%$ \\
\hline Services exports & $\$ 381 \mathrm{~B}$ & $8.44 \%$ \\
\hline Services imports & \$315B & $5.69 \%$ \\
\hline Goods exports & $\$ 895 \mathrm{~B}$ & $7.92 \%$ \\
\hline Goods imports & $\$ 1,677 \mathrm{~B}$ & $6.18 \%$ \\
\hline GDP & \$12,479B &
\end{tabular}

Note: All values are in nominal \$; average annual \% change is calculated as simple annual compounding of last year/first year Sources: BEA; CEA 
Table 4: U.S. Trade Data, 1992-2005

\begin{tabular}{|r|r|r|r|r|r|r|}
\cline { 2 - 7 } \multicolumn{1}{c|}{} & \multicolumn{3}{|c|}{ Services } & \multicolumn{3}{c|}{ Goods } \\
\hline Year & Exports & Imports & Balance & Exports & Imports & Balance \\
\hline 1992 & & & & & & \\
\hline 1993 & 186 & 124 & 62 & 457 & 589 & -132 \\
\hline 1994 & 200 & 133 & 67 & 503 & 669 & -166 \\
\hline 1995 & 219 & 141 & 78 & 575 & 749 & -174 \\
\hline 1996 & 239 & 153 & 87 & 612 & 803 & -191 \\
\hline 1997 & 256 & 166 & 90 & 678 & 876 & -198 \\
\hline 1998 & 263 & 181 & 82 & 670 & 917 & -247 \\
\hline 1999 & 282 & 199 & 83 & 684 & 1030 & -346 \\
\hline 2000 & 299 & 224 & 75 & 772 & 1224 & -452 \\
\hline 2001 & 286 & 222 & 64 & 719 & 1146 & -427 \\
\hline 2002 & 292 & 231 & 61 & 682 & 1165 & -482 \\
\hline 2003 & 303 & 250 & 52 & 713 & 1261 & -547 \\
\hline 2004 & 344 & 290 & 54 & 808 & 1473 & -665 \\
\hline 2005 & 381 & 315 & 66 & 895 & 1677 & -783 \\
\hline$\%$ & & & & & & \\
\hline $\begin{array}{l}\text { Avg. ann. } \% \\
\text { ch., 1992-2005 }\end{array}$ & 6.05 & 7.73 & & 5.62 & 9.16 & \\
\hline
\end{tabular}

Note: All values are in nominal \$; average annual \% change is calculated as simple annual compounding of last year/first year; average annual \% change in U.S. GDP, 19922005 is $5.35 \%$

Source: BEA 
Table 5: U.S. Services Trade Data, 1992-2005

(all values are in $\$$ billions)

\begin{tabular}{|c|c|c|c|c|c|c|c|c|c|c|c|c|c|c|c|c|c|c|c|c|c|c|c|c|}
\hline & \multicolumn{3}{|c|}{ Travel } & \multicolumn{3}{|c|}{ Passenger Fares } & \multicolumn{3}{|c|}{$\begin{array}{c}\text { Other } \\
\text { Transportation } \\
\end{array}$} & \multicolumn{3}{|c|}{$\begin{array}{c}\text { Royalties \& } \\
\text { License Fees }\end{array}$} & \multicolumn{3}{|c|}{$\begin{array}{c}\text { Other Private } \\
\text { Services }\end{array}$} & \multicolumn{3}{|c|}{ U. S. Military } & \multicolumn{3}{|c|}{ U.S. Gov. Misc. } & \multicolumn{3}{|c|}{ Total Services } \\
\hline Year & $\mathrm{Ex}$ & $\operatorname{Im}$ & Bal & Ex & $\mathrm{Im}$ & Bal & Ex & $\mathrm{Im}$ & Bal & Ex & $\mathrm{Im}$ & Bal & Ex & $\mathrm{Im}$ & Bal & Ex & $\mathrm{Im}$ & Bal & Ex & $\mathrm{Im}$ & Bal & Ex & $\mathrm{Im}$ & Bal \\
\hline 1992 & 55 & 39 & 16 & 17 & 11 & 6 & 22 & 24 & -2 & 21 & 5 & 16 & 50 & 25 & 25 & 12 & 14 & -1 & 1 & 2 & -1 & 177 & 120 & 58 \\
\hline 1993 & 58 & 41 & 17 & 17 & 11 & 5 & 22 & 25 & -3 & 22 & 5 & 17 & 54 & 28 & 26 & 13 & 12 & 1 & 1 & 2 & -1 & 186 & 124 & 62 \\
\hline 1994 & 58 & 44 & 15 & 17 & 13 & 4 & 24 & 26 & -2 & 27 & 6 & 21 & 61 & 32 & 29 & 13 & 10 & 3 & 1 & 3 & -2 & 200 & 133 & 67 \\
\hline 1995 & 63 & 45 & 18 & 19 & 15 & 4 & 26 & 27 & -1 & 30 & 7 & 23 & 65 & 35 & 30 & 15 & 10 & 5 & 1 & 3 & -2 & 219 & 141 & 78 \\
\hline 1996 & 70 & 48 & 22 & 20 & 16 & 5 & 26 & 27 & -1 & 32 & 8 & 25 & 73 & 40 & 34 & 16 & 11 & 5 & 1 & 3 & -2 & 239 & 153 & 87 \\
\hline 1997 & 73 & 52 & 21 & 21 & 18 & 3 & 27 & 29 & -2 & 33 & 9 & 24 & 84 & 43 & 41 & 17 & 12 & 5 & 1 & 3 & -2 & 256 & 166 & 90 \\
\hline 1998 & 71 & 56 & 15 & 20 & 20 & 0 & 26 & 30 & -5 & 36 & 11 & 24 & 92 & 48 & 44 & 17 & 12 & 5 & 1 & 3 & -2 & 263 & 181 & 82 \\
\hline 1999 & 75 & 59 & 16 & 20 & 21 & -2 & 27 & 34 & -7 & 40 & 13 & 27 & 104 & 56 & 48 & 16 & 13 & 3 & 1 & 3 & -2 & 282 & 199 & 83 \\
\hline 2000 & 82 & 65 & 18 & 21 & 24 & -4 & 30 & 41 & -12 & 43 & 16 & 27 & 108 & 61 & 47 & 14 & 13 & 0 & 1 & 3 & -2 & 299 & 224 & 75 \\
\hline 2001 & 72 & 60 & 12 & 18 & 23 & -5 & 28 & 39 & -10 & 41 & 17 & 24 & 114 & 66 & 48 & 13 & 15 & -2 & 1 & 3 & -2 & 286 & 222 & 64 \\
\hline 2002 & 67 & 59 & 8 & 17 & 20 & -3 & 29 & 38 & -9 & 45 & 19 & 25 & 122 & 73 & 50 & 12 & 19 & -7 & 1 & 3 & -2 & 292 & 231 & 61 \\
\hline 2003 & 64 & 57 & 7 & 16 & 21 & -5 & 32 & 45 & -13 & 47 & 19 & 28 & 131 & 80 & 51 & 13 & 25 & -13 & 1 & 3 & -2 & 303 & 250 & 52 \\
\hline 2004 & 75 & 66 & 9 & 19 & 24 & -5 & 37 & 54 & -17 & 53 & 23 & 29 & 145 & 90 & 54 & 15 & 29 & -14 & 1 & 4 & -3 & 344 & 290 & 54 \\
\hline 2005 & 82 & 69 & 13 & 21 & 26 & -5 & 42 & 62 & -20 & 57 & 25 & 33 & 158 & 99 & 60 & 19 & 30 & -11 & 1 & 4 & -3 & 381 & 315 & 66 \\
\hline $\begin{array}{l}\text { Avg ann \% } \\
\text { ch, 1992- } \\
2005\end{array}$ & 3.13 & 4.60 & & 1.79 & 7.16 & & 5.32 & 7.67 & & 8.11 & 12.73 & & 9.22 & 11.01 & & 3.36 & 6.15 & & 1.99 & 4.44 & & 6.05 & 7.73 & \\
\hline
\end{tabular}

Note: All values are in nominal \$; average annual \% change is calculated as simple annual compounding of last year/first year; average annual \% change in U.S. GDP, 1992-2005 is 5.35\%

Source: BEA 
Table 6: Sales of Services through Affiliates

\begin{tabular}{|r|r|r|r|}
\hline Year & $\begin{array}{c}\text { Sales to foreign } \\
\text { persons by foreign } \\
\text { nonbank affiliates of } \\
\text { U.S. Companies }\end{array}$ & $\begin{array}{c}\text { Sales to U.S. persons } \\
\text { by U.S. nonbank } \\
\text { affiliates of foreign } \\
\text { companies }\end{array}$ & Difference \\
\hline 1992 & \$141B & \$128B & $\$ 13 B$ \\
\hline 1993 & 143 & 135 & 8 \\
\hline 1994 & 159 & 145 & 14 \\
\hline 1995 & 190 & 150 & 40 \\
\hline 1996 & 223 & 168 & 55 \\
\hline 1997 & 255 & 223 & 32 \\
\hline 1998 & 286 & 246 & 40 \\
\hline 1999 & 353 & 294 & 59 \\
\hline 2000 & 414 & 344 & 70 \\
\hline 2001 & 422 & 368 & 54 \\
\hline 2002 & 424 & 368 & 56 \\
\hline 2003 & 452 & 374 & 78 \\
\hline 2004 & 490 & 383 & 107 \\
\hline & 10.94 & 9.56 & \\
\hline $\begin{array}{l}\text { Avg. ann. } \% \\
\text { ch., } 1992-2004\end{array}$ & & & \\
\hline
\end{tabular}

Source: Koncz et al. (2006). 